\title{
Rat $\alpha_{2}$ Acute-Phase Macroglobulin
}

\section{ISOLATION AND PHYSICOCHEMICAL PROPERTIES}

\author{
By FRANCIS GAUTHIER* and HENRI MOURAY $\dagger$ \\ *Laboratory of Biochemistry, Faculty of Sciences, Parc de Grandmont, \\ 37200 Tours, France, and †Laboratory of Biochemistry, Faculty of Medicine, \\ Boulevard Tonnellé, 37032 Tours Cedex, France
}

(Received 5 July 1976)

\begin{abstract}
1. Rat $\alpha_{2}$ acute-phase macroglobulin was isolated from turpentine-injected rats by Sephadex G-200 chromatography and ion-exchange chromatography on DEAE-cellulose. This method, since it does not include $\left(\mathrm{NH}_{4}\right)_{2} \mathrm{SO}_{4}$ treatment, allows the study of the physicochemical as well as the biological properties of the molecule. 2 . The purity of the preparation was demonstrated by ultracentrifugation, polyacrylamide-gel electrophoresis, fused 'rocket' immunoelectrophoresis as well as double immunodiffusion. 3. The rat $\alpha_{2}$ acute-phase macroglobulin was characterized in terms of its main physical and chemical properties. Its isoelectric point was determined by isoelectrofocusing to be 4.55; $s_{20, w}^{0}$ was $18.4 \mathrm{~S}$ and $E_{1 \mathrm{~m}}^{1 \%}$ at $278 \mathrm{~nm}$ was 6.8 . The mol.wt. was determined by lightscattering to be 770000 . 4. The amino acid content was compared with that of rat $\alpha_{1}$ macroglobulin and was found very similar. The carbohydrate composition of $\alpha_{2}$ acutephase macroglobulin was determined to be: hexose, $4.25 \%$; glucosamine, $3.4 \%$; sialic acid, $2 \%$; fucose, $0.2 \%$. From these results it was concluded that $\alpha_{2}$ acute-phase macroglobulin, although a typical acute-phase reactant, possesses the characteristic physicochemical properties of $\alpha$ macroglobulins.
\end{abstract}

Rat $\alpha_{2}$ acute-phase macroglobulin has been demonstrated under a variety of physiological and pathological conditions (Darcy, 1955; Beaton et al., 1961; Heim, 1962, 1964; Fine et al., 1962). Later, this protein was found in normal adult rats (Eddington et al., 1972; Ganrot, 1973a) and its concentration determined by means of electroimmunoassay.

Evidence for hepatic synthesis of $\alpha_{2}$ acute-phase macroglobulin was presented by Sarcione \& Bogden (1966); isolation was first performed by Menninger et al. (1970), and Jamieson et al. (1972) determined some of its physicochemical properties. Interaction with trypsin and plasmin was described by Ganrot $(1973 b)$. The comparative study of the enzyme binding capacity of rat $\alpha_{2}$ acute-phase macroglobulin and rat $\alpha_{1}$ macroglobulin (present in the serum of normal adult rat) has given very similar results (Gauthier \& Mouray, 1975b), suggesting an identical molecular structure of the two proteins around the binding site. However, their antigenic properties as well as their physiological variations are unrelated. A further investigation of the physicochemical properties of $\alpha_{2}$ acute-phase macroglobulin was necessary to try to explain the metabolism of this protein.

The purpose of this work was to isolate rat $\alpha_{2}$ acute-phase macroglobulin and determine its main physicochemical constants as well as amino acid and carbohydrate content.

\section{Experimental \\ Isolation procedure}

Blood collection. Two normal adult male rats (Wistar C.F., 300-500g body wt.) were injected subcutaneously with turpentine $(0.5 \mathrm{ml} / 100 \mathrm{~g}$ body wt.). Blood was collected $48 \mathrm{~h}$ later by cardiac puncture under light diethyl ether anaesthesia. After clot formation and centrifugation about $15-20 \mathrm{ml}$ of serum was obtained and subjected to the first step of the isolation procedure.

Gel filtration on Sephadex G-200. Initially, the serum was subjected to chromatography on Sephadex G-200; the column $(2.5 \mathrm{~cm} \times 100 \mathrm{~cm})$ was equilibrated in $0.1 \mathrm{M}-\mathrm{Tris} / \mathrm{HCl}(\mathrm{pH} 7.4) / 0.15 \mathrm{M}-\mathrm{NaCl}$. One portion of the first eluted peak (Fig. 1a) containing mainly $\alpha_{1}$ macroglobulin and $\alpha_{2}$ acute-phase macroglobulin was collected and subjected to the second step of isolation.

Ion-exchange chromatography on DEAE-cellulose. The collected fractions $(40-50 \mathrm{ml})$ were dialysed in $0.05 \mathrm{M}-\mathrm{Tris} / \mathrm{HCl}(\mathrm{pH} 8) / 0.03 \mathrm{M}-\mathrm{NaCl}$ and subdivided in two parts of about $25 \mathrm{ml}$ each; ion-exchange chromatography was performed on one of the portions with a linear concentration gradient by using a modification of Ganrot's (1973a) method; for this experiment $250 \mathrm{ml}$ of equilibrating buffer and $250 \mathrm{ml}$ of $0.05 \mathrm{M}$-Tris $/ \mathrm{HCl}(\mathrm{pH} 8) / 0.20 \mathrm{M}-\mathrm{NaCl}$ were used. The elution diagram (Fig. 1b) shows two main peaks. 

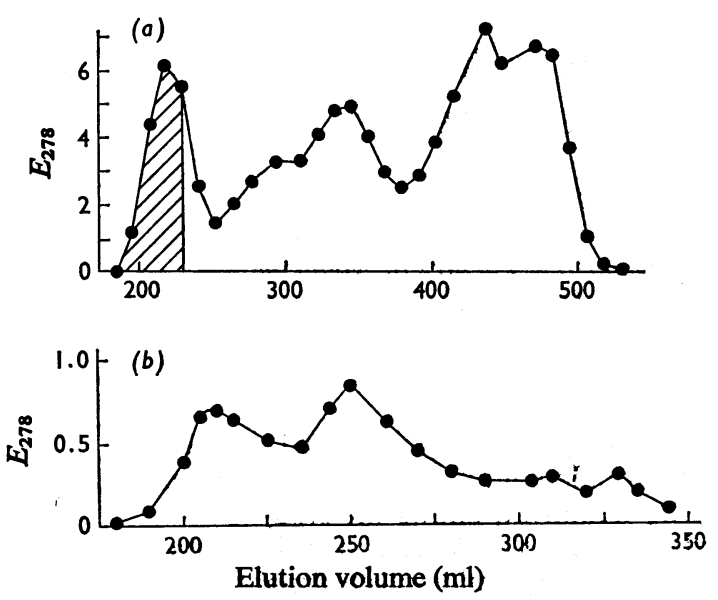

Fig. 1. Purification of rat $\alpha_{2}$ acute-phase macroglobulin

(a) Elution pattern after the first stage of the preparation with Sephadex G-200 chromatography; (b) the fraction indicated by hatching in $(a)$ was further separated by DEAE-cellulose ion-exchange chromatography.

$\alpha_{2}$ acute-phase macroglobulin has been shown to be eluted in the first peak, since it reacts with anti(inflammatory rat serum), but not anti-(normal rat serum) antiserum. The $\mathrm{NaCl}$ concentration at the $\alpha_{2}$ acute-phase macroglobulin elution volume was approx. $78 \mathrm{~mm}$.

\section{Methods}

Electrophoresis. Fused 'rocket' immunoelectrophoresis was used as described by Svendsen \& Rose (1970); the experiments were performed in $1 \%(\mathrm{w} / \mathrm{v})$ agarose $/ 0.075 \mathrm{M}$-barbital $(\mathrm{pH} 8.6) / 2 \%(\mathrm{w} / \mathrm{v})$ calcium lactate with a voltage gradient of $3 \mathrm{~V} / \mathrm{cm}$ for $15 \mathrm{~h}$. Anti-( $\alpha_{2}$ acute-phase macroglobulin) antiserum was prepared in rabbits (strain Fauve de Bourgogne) by injecting $1.8 \mathrm{ml}$ of a $1: 1(\mathrm{v} / \mathrm{v})$ emulsion of antigen $(1 \mathrm{mg} / \mathrm{ml})$ and complete Freund's adjuvant. Intradermal injections were made dorsally at 10 to 15 different points and were repeated 15 days later. The blood was collected by cardiac puncture at least 8 days after the second injection. Anti-(normal rat serum) antiserum was from Behringwerke A.-G., Marburg, Germany.

Polyacrylamide-disc-gel electrophoresis was performed by the method of Davis (1964) in $5.5 \%(\mathrm{w} / \mathrm{v})$ gel. The experiments were performed in Tris/glycine buffer, pH 8.3, with a current of $4 \mathrm{~mA} / \mathrm{gel}$. Staining was done with $1 \%$ Amido Black.

Physical measurements. Determination of the isoelectric point was by isoelectrofocusing in a sucrose gradient and with carrier ampholites (pH range 4-6) in a LKB 8100 column (Vesterberg \& Svensson,
1966). Approx. $25 \mathrm{mg}$ of $\alpha_{2}$ acute-phase macroglobulin was initially desalted by gel filtration on a Sephadex G-25 column $(1 \mathrm{~cm} \times 10 \mathrm{~cm})$ and then applied to the column. A voltage not exceeding $400 \mathrm{~V}$ was applied during the experiment, which lasted $48 \mathrm{~h}$ at $4^{\circ} \mathrm{C}$. Measurements of $E_{278}$ and the pH were made on eluted fractions of $2 \mathrm{ml}$ each.

Sedimentation coefficients were obtained by using the Beckman Spinco ultracentrifuge at 44000 rev./ min and $20^{\circ} \mathrm{C}$. The $\alpha_{2}$ acute-phase macroglobulin solutions were equilibrated in $0.05 \mathrm{M}-\mathrm{Tris} / \mathrm{HCl}(\mathrm{pH} 8) /$ $0.07 \mathrm{M}-\mathrm{NaCl}$, at concentrations of $2.36,5.15$ and $8.46 \mathrm{mg} / \mathrm{ml}$. The sedimentation values were determined by the method of Schachman (1957) and converted into $s$ values in water at $20^{\circ} \mathrm{C}\left(s=s_{\text {obs. }} \times 1.019\right)$.

The molecular weight of $\alpha_{2}$ acute-phase macroglobulin was calculated by light-scattering by using the Wippler and Scheibling photogoniodiffusometer; $\alpha_{2}$ acute-phase macroglobulin was equilibrated in $0.05 \mathrm{M}-\mathrm{Tris} / \mathrm{HCl}(\mathrm{pH} 8) / 0.15 \mathrm{M}-\mathrm{NaCl}$ and filtered twice through a $0.45 \mu \mathrm{m}$ Millipore membrane. Molecular weight was determined by means of the following equation:

$$
\frac{1}{M}=K I_{B}\left(\frac{\mathrm{d} n}{\mathrm{~d} c}\right)^{2}\left(\frac{c}{\Delta i}\right)_{c=0,0=0}
$$

where $M$ is the molecular weight, $K$ is a constant depending on the wavelength of the incident light $(546 \mathrm{~nm})$ and on the Rayleigh ratio of the standard solution (benzene), and $c$ is the concentration. The refractive-index increment $\mathrm{d} n / \mathrm{d} c$ was found to be $0.18 \mathrm{ml} / \mathrm{g}$. $\Delta i$ and $I_{B}$ (light scattered by the sample and the standard respectively at an angle of $90^{\circ}$ ) were determined experimentally.

Chemical analysis. Nitrogen determination was performed by the micro Kjeldahl procedure. Proteins were determined both with the biuret reagent method and by the method of Lowry et al. (1951), with bovine serum albumin as standard.

Total hexose content was measured by the orcinol/ sulphuric acid method (Tillmans \& Philippi, 1929) adapted to the Technicon autoanalyser by Demaille et al. (1965). An equimolar solution of D-galactose and D-mannose was used as a standard. The minor degree of fucose interference was not deducted.

Approx. $1.5 \mathrm{mg}$ of protein was dissolved in $4 \mathrm{M}-\mathrm{HCl}$ and hydrolysed in a sealed tube for $4 \mathrm{~h}$ at $100^{\circ} \mathrm{C}$ to determine the hexosamine content. Hexosamines were measured by the method of Neuhaus \& Letzring (1957) and were identified during the amino acid analysis by using the Technicon autoanalyser.

Fucose was determined by the Dische \& Shettles (1948) reaction. Sialic acid was measured as described by Aminoff (1961); hydrolysis was performed in $0.05 \mathrm{M}-\mathrm{H}_{2} \mathrm{SO}_{4}$ for $30 \mathrm{~min}$ at $80^{\circ} \mathrm{C}$.

For the amino acid analysis approx. $1.5 \mathrm{mg}$ of $\alpha_{2}$ acute-phase macroglobulin was hydrolysed for periods of 24 and $48 \mathrm{~h}$ in $1 \mathrm{ml}$ of $5.6 \mathrm{M}-\mathrm{HCl}$ at $105^{\circ} \mathrm{C}$. 


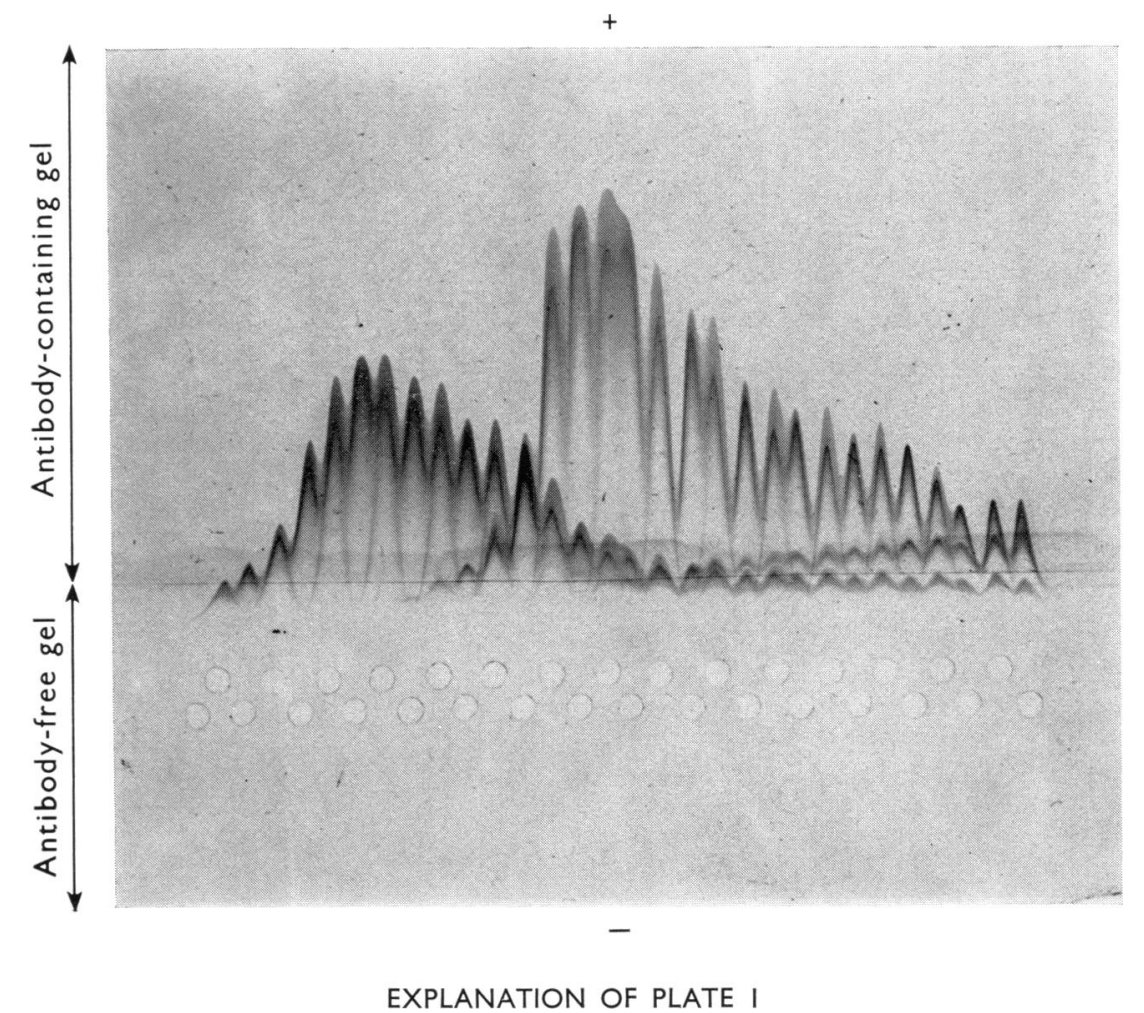

Fused 'rocket' immunoelectrophoresis of fractions obtained after the second stage of separation

Anti-(normal rat serum) antiserum $(0.3 \mathrm{ml})$ and $0.3 \mathrm{ml}$ of anti-(rat $\alpha_{2}$ acute-phase macroglobulin) antiserum were mixed with the antibody-containing gel; $5 \mu$ l of each eluted fraction was applied to the wells of antibody-free gel and analysed as described in the Experimental section. 


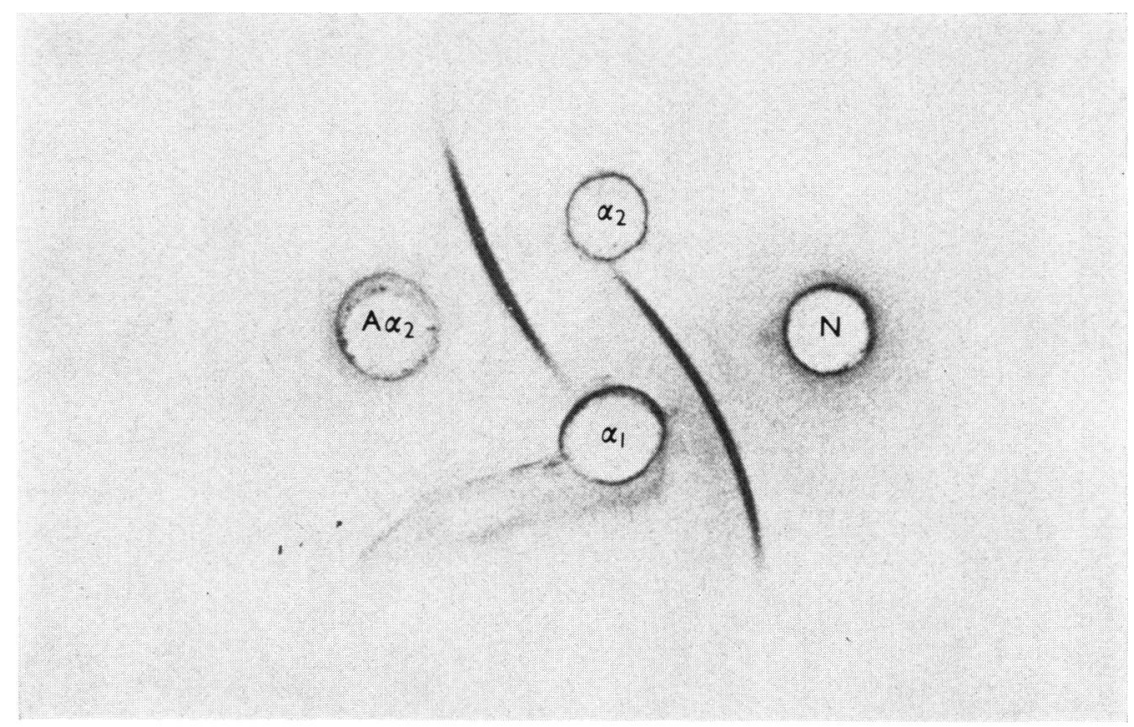

EXPLANATION OF PLATE 2

Ouchterlony double immunodiffusion

Pooled fractions $(10 \mu \mathrm{l})$ of $\alpha_{2}$ acute-phase macroglobulin $\left(\alpha_{2}\right)$ following the second stage of the purification reacted with anti(normal rat serum) antiserum $(\mathrm{N})$ and anti- $\left(\alpha_{2}\right.$ acute-phase macroglobulin) antiserum $\left(\mathrm{A} \alpha_{2}\right)$. The other well contained rat $\alpha_{1}$ macroglobulin. 


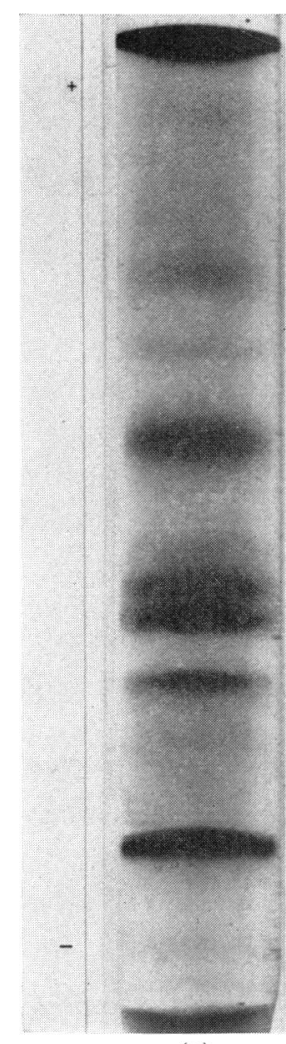

(a)

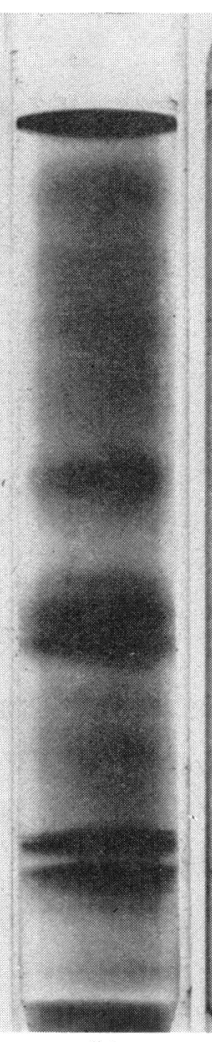

(b)

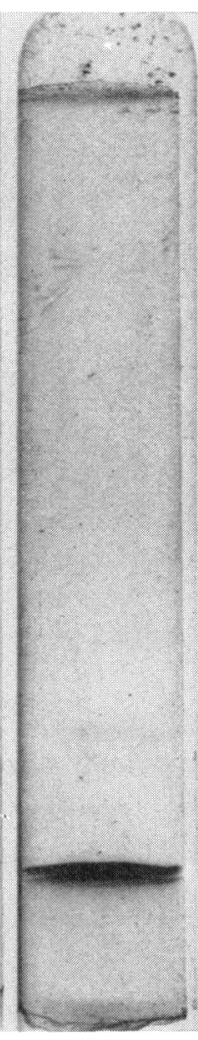

(c)

\section{EXPLANATION OF PLATE 3 \\ Disc-gel electrophoresis}

(a) Normal rat serum, (b) inflammatory rat serum, $(c) \alpha_{2}$ acute-phase macroglobulin after the second stage of purification. 


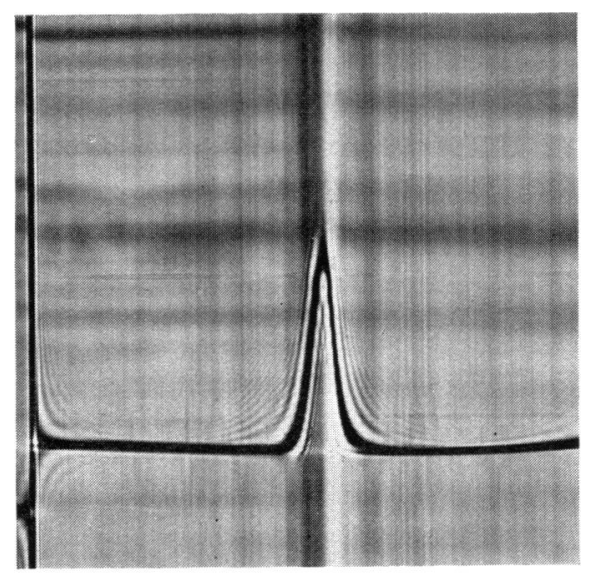

EXPLANATION OF PLATE 4

Ultracentrifugation pattern of purified $\alpha_{2}$ acute-phase macroglobulin

The protein concentration was $5.15 \mathrm{mg} / \mathrm{ml}$; the photograph was taken at a schlieren angle of $70^{\circ} 44 \mathrm{~min}$ after top speed was reached. Sedimentation is from left to right. 
Table 1. Physical properties of rat and human $\alpha$-macroglobulins

References: ", Gauthier et al. (1974); ', Schönenberger et al. (1958); ${ }^{\circ}$, Jones et al. (1972).

\begin{tabular}{lcrc} 
& \multicolumn{3}{c}{ Macrogiobulin properties } \\
& $\begin{array}{c}\text { Rat } \alpha_{2} \\
\text { acute phase }\end{array}$ & Rat $\alpha_{1}$ & Human $\alpha_{2}$ \\
$E_{1 \%}^{1 \%}(278 \mathrm{~nm})$ & 6.8 & $8.5^{\mathrm{a}}$ & $8.1^{\mathrm{b}}$ \\
pI & 4.55 & $4.4^{\mathrm{a}}$ & $5_{.4}^{\mathrm{b}}$ \\
$s_{20, \mathrm{~m}}^{0}(\mathrm{~S})$ & 18.4 & $17.8^{\mathrm{a}}$ & $19.6^{\mathrm{b}}$ \\
Mol.wt. & 770000 & $760000^{\mathrm{a}}$ & $725000^{\mathrm{c}}$
\end{tabular}

Excess of $\mathrm{HCl}$ was removed by desiccation over $\mathrm{NaOH}$ pellets in vacuo. Residues were dissolved in citrate buffer $/ 12.5 \%(\mathrm{w} / \mathrm{v})$ sucrose, $\mathrm{pH} 2.2$, containing leucine standard. $\alpha_{1}$ Macroglobulin was studied by using the same procedure; purification of this protein has been previously described (Gauthier et al., 1974).

\section{Results}

\section{Purity criteria}

The purity of the material obtained after the two stages of preparation was investigated by electrophoresis, double-immunodiffusion and ultracentrifugation techniques. Fused 'rocket' immunoelectrophoresis (Plate 1) shows the distribution of proteins after the ion-exchange chromatography. The first eluted fractions containing $\alpha_{2}$ acute-phase macroglobulin were pooled and purity was further checked by double immunodiffusion (Plate 2).

Engler et al. (1972) mentioned the difficulty in distinguishing between $\alpha_{1}$ macroglobulin and $\alpha_{2}$ acute-phase macroglobulin with disc electrophoresis. A good separation was obtained when electrophoresis was performed in $5.5 \%$ gels (Plates $3 a$ and $3 b$ ). $\alpha_{2}$ Acute-phase macroglobulin appears as a double band (Plate 3c). Only one band with a slightly increased mobility was observed after incubation with chymotrypsin. The same result has been previously obtained with rat $\alpha_{1}$ macroglobulin (Gauthier \& Mouray, 1975a).

The ultracentrifugation of purified $\alpha_{2}$ acute-phase macroglobulin showed no traces of impurity (Plate 4).

\section{Physical properties}

The results are summarized in Table 1 and compared with those obtained for rat $\alpha_{1}$ macroglobulin and human $\alpha_{2}$ macroglobulin.

Spectrophotometry. The spectrum of ultraviolet absorption shows the characteristic profile of proteins with maximum absorption at $278 \mathrm{~nm}$. No significant absorption was found above $330 \mathrm{~nm}$. The extinction

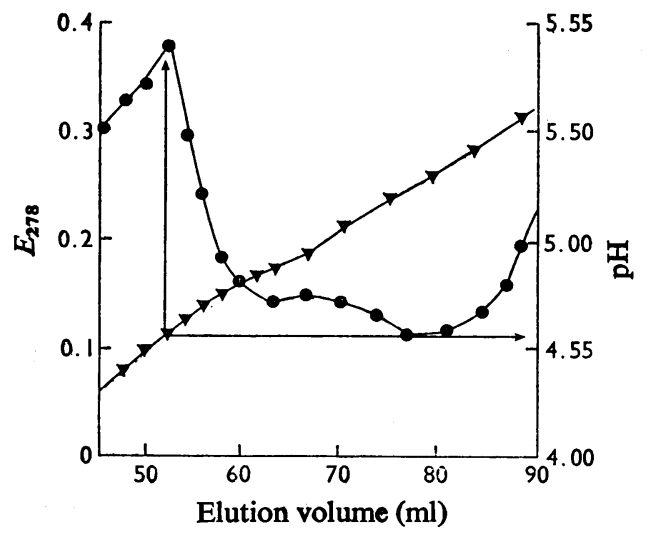

Fig. 2. Isoelectric focusing of $\alpha_{2}$ acute-phase macroglobulin Fractions $(2 \mathrm{ml}$ each) were collected after $48 \mathrm{~h}$ under a maximal voltage of $400 \mathrm{~V} . \nabla, \mathrm{pH} ; \bullet, E_{278}$.

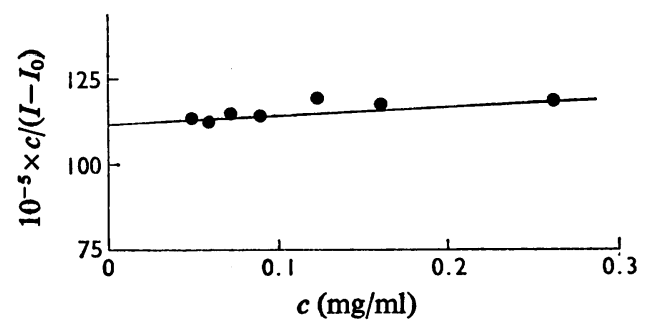

Fig. 3. Molecular weight of $\alpha_{2}$ acute-phase macroglobulin $c /\left(I-I_{0}\right)$ was determined by extrapolation from experimental values to zero concentration.

coefficient was measured with the Beckman DB spectrophotometer at $278 \mathrm{~nm}$. The $\alpha_{2}$ acute-phase macroglobulin solution was desiccated at $60^{\circ} \mathrm{C}$ under an increasing vacuum. A value of $E_{1 \mathrm{~cm}}^{1 \%}$ at $278 \mathrm{~nm}$ of 6.8 was obtained in $0.1 \mathrm{M}$-Tris/ $/ \mathrm{HCl}, \mathrm{pH} 8$.

Isoelectric point. After isoelectric focusing with carrier ampholites, the purified $\alpha_{2}$ acute-phase macroglobulin was focused as a single peak at pH4.55 (Fig. 2).

Sedimentation coefficient. The values of $s_{20, w}$ for $\alpha_{2}$ acute-phase macroglobulin concentrations of $2.36,5.15$ and $8.46 \mathrm{mg} / \mathrm{ml}$ were $17.83,16.67$ and $15.90 \mathrm{~S}$ respectively. Extrapolation to zero concentration gave a value of $s_{20, \mathrm{w}}^{0}=18.4 \mathrm{~S}$.

Molecular weight. The scattered light was measured at seven $\alpha_{2}$ acute-phase macroglobulin dilutions $(0.048-0.217 \mathrm{mg} / \mathrm{ml})$ in order to extrapolate to zero concentration (Fig. 3). The mol.wt. found was $770000 \pm 40000$.

Vol. 159 
Table 2. Amino acid composition of rat $\alpha_{2}$ acute-phase macroglobulin and rat $\alpha_{1}$ macroglobulin (two analyses)

\begin{tabular}{lcc} 
& \multicolumn{2}{c}{ Composition $(\mathrm{mol} / 100 \mathrm{~mol})$} \\
\cline { 2 - 3 } Amino acid & $\begin{array}{c}\text { Rat } \alpha_{2} \text { acute-phase } \\
\text { macroglobulin }\end{array}$ & $\begin{array}{c}\text { Rat } \alpha_{1} \\
\text { macroglobulin }\end{array}$ \\
Lys & $5.69 \pm 0.16$ & $6.22 \pm 0.21$ \\
His & $1.58 \pm 0.05$ & $2.14 \pm 0.11$ \\
Arg & $3.63 \pm 0.12$ & $3.09 \pm 0.13$ \\
Asp & $8.67 \pm 0.09$ & $9.63 \pm 0.3$ \\
Thr & $6.97 \pm 0.13$ & $6.72 \pm 0.09$ \\
Ser & $7.28 \pm 0.01$ & $7.55 \pm 0.25$ \\
Glu & $12.32 \pm 0.23$ & $12.32 \pm 0.12$ \\
Pro & $5.02 \pm 0.09$ & $5.16 \pm 0.21$ \\
Gly & $6.46 \pm 0.19$ & $6.10 \pm 0.05$ \\
Ala & $7.12 \pm 0.06$ & $6.83 \pm 0.19$ \\
Cys (half) & $1.28 \pm 0.2$ & $1.68 \pm 0.07$ \\
Val & $8.67 \pm 0.04$ & $8.29 \pm 0.22$ \\
Met & $2.06 \pm 0.15$ & $1.92 \pm 0.14$ \\
Ile & $4.33 \pm 0.06$ & $5.18 \pm 0.2$ \\
Leu & $11.05 \pm 0.10$ & $9.11 \pm 0.08$ \\
Tyr & $3.40 \pm 0.2$ & $3.85 \pm 0.03$ \\
Phe & $4.46 \pm 0.03$ & $4.13 \pm 0.03$
\end{tabular}

Table 3. Carbohydrate composition

Results are expressed as percentage of dry weight.

\begin{tabular}{lcc} 
& \multicolumn{2}{c}{ Composition (\%) } \\
\cline { 2 - 3 } $\begin{array}{c}\alpha_{2} \text { acute-phase } \\
\text { macroglobulin }\end{array}$ & $\begin{array}{c}\alpha_{1} \\
\text { macroglobulin }\end{array}$ \\
Hexose & 4.25 & 3.2 \\
Hexosamine & 3.4 & 3.4 \\
Fucose & 0.20 & 0.45 \\
Sialic acid & 2.0 & 2.1
\end{tabular}

\section{Chemical analysis}

Rat $\alpha_{2}$ acute-phase macroglobulin contains $85 \%$ protein (mean value). The nitrogen content of the protein has an average value of $12.3 \%$.

Amino acid analysis. The results of the quantitative amino acid determination are summarized in Table 2, which also shows for comparison those values obtained for rat $\alpha_{1}$ macroglobulin. Most of the amino acids were released after $24 \mathrm{~h}$ of hydrolysis.

Carbohydrate composition. The values obtained (Table 3) are in good agreement with those found for other species, but differ from those reported for rat $\alpha_{2}$ acute-phase macroglobulin by Jamieson et al. (1972). Hexosamines were identified as being essentially glucosamine. No significant difference was found between the two rat macroglobulins.

\section{Discussion}

Since this method of preparation of $\alpha_{2}$ acute-phase macroglobulin does not include $\left(\mathrm{NH}_{4}\right)_{2} \mathrm{SO}_{4}$ treatment, it permits the study of the structural and physicochemical properties of the molecule as well as of its biological activity, particularly its enzyme binding capacity. Mehl et al. (1964) underlined the disadvantage encountered in using $\left(\mathrm{NH}_{4}\right)_{2} \mathrm{SO}_{4}$ during human $\alpha_{2}$ macroglobulin isolation in experiments designed to study its interaction with trypsin.

Comparison of $\alpha_{1}$ macroglobulin and $\alpha_{2}$ acutephase-macroglobulin physical constants shows many similarities between these two proteins. This explains the difficulties encountered during the second step of the separation procedure. However, the use of a very slowly increasing $\mathrm{NaCl}$ gradient during ion-exchange chromatography gave a yield of $20-25 \%$ of $\alpha_{2}$ acute-phase macroglobulin. This value was estimated by reference to the $\alpha_{2}$ acute-phase macroglobulin concentration in inflammatory serum by using the electroimmunoassay; $\alpha_{2}$ acute-phase macroglobulin content was determined as varying between 2 and $9 \mathrm{~g} /$ litre $48 \mathrm{~h}$ after a turpentine injection.

Ultracentrifugation, as well as immunological criteria, does not permit demonstration of any contaminants.

Only $\alpha_{2}$ acute-phase macroglobulin was purified by this present procedure, as can be seen in Plate 1. Isolation of $\alpha_{1}$ macroglobulin from injured rats can be realized by using preparative isotachophoresis (F. Gauthier, unpublished work). Pure $\alpha_{1}$ macroglobulin is then eluted before the $\alpha_{2}$ acute-phase macroglobulin.

The amino acid and carbohydrate contents of the two macroglobulins were shown to be very similar and are in close agreement with the results reported for $\alpha$ macroglobulin obtained from other species. However, Jamieson et al. (1972) obtained a higher hexose content $(9.3 \%)$ during $\alpha_{2}$ acute-phasemacroglobulin carbohydrate analysis. They also found a slightly higher sialic acid content $(2.6 \%)$. No fucose was found.

The present study indicates that rat $\alpha_{2}$ acute-phase macroglobulin possesses all the physicochemical properties characteristic of $\alpha$ macroglobulins; no significant differences from rat $\alpha_{1}$ macroglobulin can be demonstrated, which would explain the role of $\alpha_{2}$ acute-phase macroglobulin in response to inflammation or other acute processes. However, $\alpha_{1}$ macroglobulin, which normally binds and regulates the activity of proteolytic enzymes, does not increase during inflammation, despite the liberation of proteolytic enzymes, particularly from injured cells. $\alpha_{2}$ acute-phase macroglobulin could act in the same way as $\alpha_{1}$ macroglobulin; experiments done in vitro have demonstrated the same binding capacities for trypsin and chymotrypsin (Gauthier \& Mouray, 1975b). A 
factor related to the liberation of enzymes could intervene as a 'de-repressor' of the $\alpha_{2}$ acute-phasemacroglobulin synthesis (Sarcione, 1970) since it is known that $\alpha_{2}$ acute-phase macroglobulin is normally present in the blood of the foetal and young rat, and diminishes after parturition.

We are grateful to Dr. A. H. Gordon (National Institute for Medical Research, London, U.K.) for helpful criticisms of this manuscript. We acknowledge the help of Dr. M. Leng and the technical assistance of Mrs. G. Serros who carried out the ultracentrifugations (C.B.M. du C.N.R.S. Orleans-La Source). This work was supported by a grant from D.G.R.S.T. (no. 7570189).

\section{References}

Aminoff, D. (1961) Biochem. J. 81, 384-392

Beaton, G. H., Selby, A. E., Veen, M. J. \& Wright, A. M. (1961) J. Biol. Chem. 236, 2005-2008

Darcy, D. A. (1955) Nature (London) 176, 643-644

Davis, B. J. (1964) Ann. N. Y. Acad. Sci. 121, 404-427

Demaille, J., Dautrevaux, M., Havez, R. \& Biserte, G. (1965) Bull. Soc. Chim. Fr. 12, 3506-3509

Dische, Z. \& Schettles, L. B. (1948) J. Biol. Chem. 175, 595-603

Eddington, C. L., Upchurch, H. F. \& Kampschmidt, R. F. (1972) Proc. Soc. Exp. Biol. Med. 139, 565-569

Engler, R., Lombart, C. \& Jayle, M. F. (1972) Biochem. Biophys. Res. Commun. 46, 1483-1487

Fine, J. M., Boffa, G. A. \& Zajdela, F. (1962) C. R. Hebd. Séances Acad. Sci. Ser. D 255, 1045-1047
Ganrot, K. (1973a) Biochim. Biophys. Acta 295, 245-251

Ganrot, K. (1973b) Biochim. Biophys. Acta 322, 62-67

Gauthier, F. \& Mouray, H. (1975a) Int. J. Biochem. 6, 95-98

Gauthier, F. \& Mouray, H. (1975b) Protides Biol. Fluids Proc. Colloq. 23, 139-143

Gauthier, F., Leng, M. \& Mouray, H. (1974) C. R. Hebd. Séances Acad. Sci. Ser. D 279, 1409-1412

Heim, W. G. (1962) Nature (London) 193, 491

Heim, W. G. (1964) Nature (London) 203, 1077-1078

Jamieson, J. C., Friesen, A. D., Ashton, F. E. \& Chou, B. (1972) Can. J. Biochem. 50, 856-870

Jones, J. M., Creeth, J. N. \& Kekwick, R. A. (1972) Biochem. J. 187, 187-197

Lowry, O. H., Rosebrough, N. J., Farr, A. L. \& Randall, R. J. (1951) J. Biol. Chem. 193, 265-275

Mehl, J. W., O’Connell, W. \& De Groot, J. (1964) Science 145, 821-822

Menninger, F. F., Esber, H. J. \& Bogden, A. E. (1970) Clin. Chim. Acta 27, 385-394

Neuhaus, O. W. \& Letzring, M. (1957) Anal. Biochem. 29, 1230-1233

Sarcione, E. J. (1970) Biochemistry 9, 3059-3062

Sarcione, E. J. \& Bogden, A. E. (1966) Science 153, 547548

Schachman, N. K. (1957) Methods Enzymol. 4, 32-103

Schönenberger, H. E., Schmidtberger, R. \& Schultze, H. E. (1958) Z. Naturforsch. Teil B 13, 761-772

Svendsen, P. J. \& Rose, C. (1970) Sci. Tools 17, 13-17

Tillmans, J. \& Philippi, K. (1929) Biochem. Z. 215, 36-60

Vesterberg, O. \& Svensson, H. (1966) Acta Chem. Scand. 20, 820-834 